Division of Geological \& Geophysical Surveys

\author{
PRELIMINARY INTERPRETIVE REPORT 2016-2
}

\title{
PRELIMINARY REPORT ON MINERAL OCCURRENCES IN THE TOK RIVER AREA, ALASKA
}

by

Evan Twelker, Larry K. Freeman, Karri R. Sicard, and Alexandra C. Busk

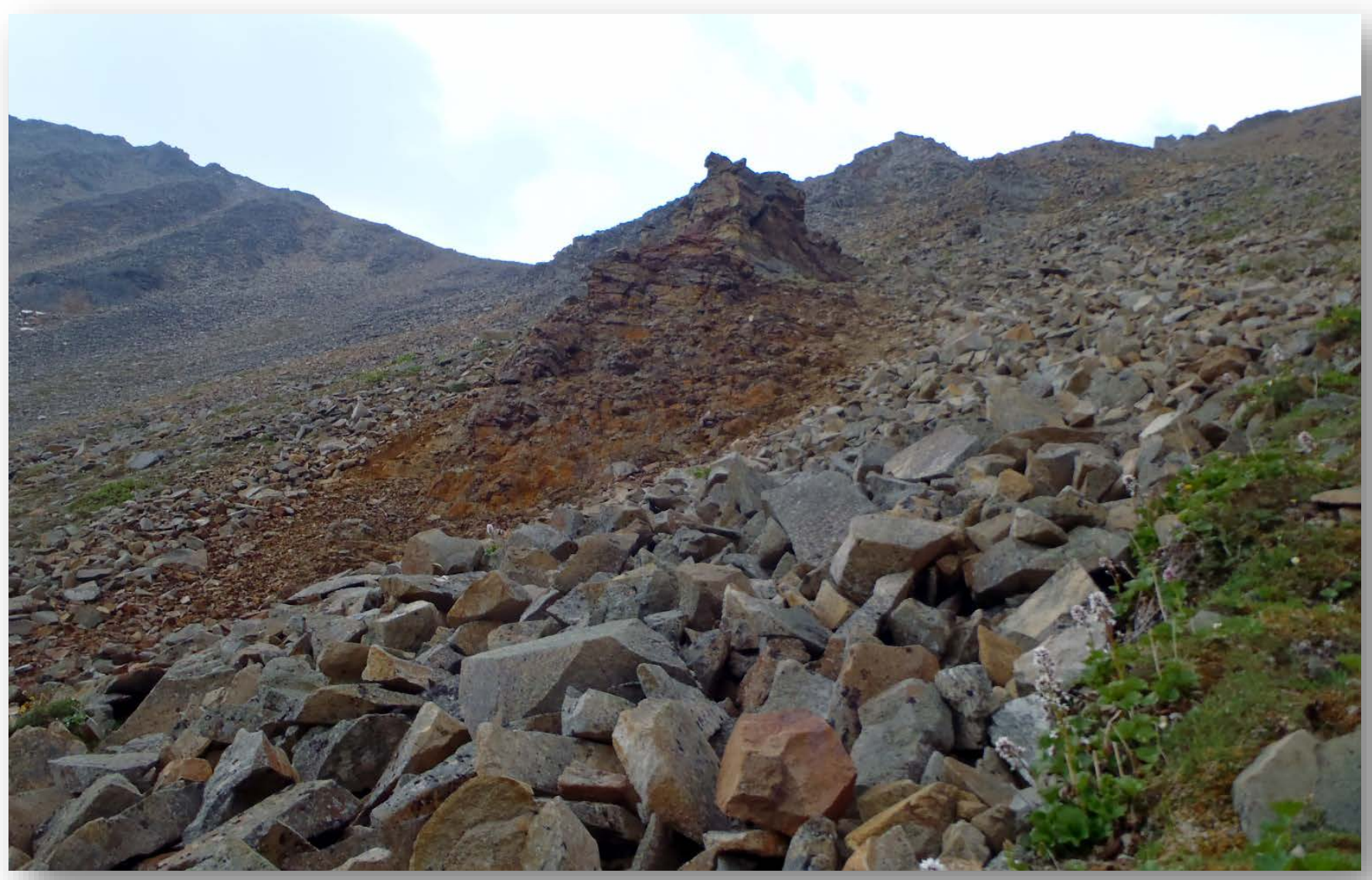

An outcrop of gossanous schist surrounded by talus of altered intrusive rocks at the Hona prospect. Photo by Evan Twelker.

This publication is PRELIMINARY in nature and is meant to allow rapid release of field observations or initial interpretations of geology or analytical data. It has not undergone formal peer review.

Interpretations or conclusions contained in this publication are subject to change.

2016

STATE OF ALASKA

DEPARTMENT OF NATURAL RESOURCES

DIVISION OF GEOLOGICAL \& GEOPHYSICAL SURVEYS

3354 College Road, Fairbanks, AK 99709-3707 • 907-451-5010

dggspubs@alaska.gov • www.dggs.alaska.gov 


\section{PRELIMINARY REPORT ON MINERAL OCCURRENCES IN THE TOK RIVER}

\section{AREA, ALASKA}

Evan Twelker ${ }^{1}$, Larry K. Freeman ${ }^{1}$, Karri R. Sicard ${ }^{1}$, and Alexandra C. Busk ${ }^{2}$

\section{INTRODUCTION}

Geologists from the Alaska Division of Geological \& Geophysical Surveys spent 10 days between June 19 and June 28 doing preliminary geologic reconnaissance of the Tok River area in preparation for a proposed 2016 mapping project. During the course of this reconnaissance, the field crew collected additional geologic observations and geochemical data for several mineral occurrences and one inactive placer mine. This report summarizes these observations and will be used to update the Alaska Resource Data File (ARDF) records for the project area. The ARDF is a mineral occurrence database maintained by the U.S. Geological Survey; it is available online at:

http://ardf.wr.usgs.gov/.

\section{AREA GEOLOGY}

The project area is underlain by Paleozoic metamorphic rocks of the Macomb, Jarvis Creek, and Hayes Glacier belts (fig. 1; Nokleberg and others, 2015; Foster, 1970). Amphibolite-grade gneiss and schist of the Macomb belt (Nokleberg and others, 2015) occupy the northeastern portion of the map. The Devonian metasedimentary and metavolcanic schists of the Jarvis belt (Nokleberg and others, 2015; Dashevsky and others, 2003) structurally overlie the Macomb belt along the regional Elting Creek fault. The structurally highest rocks, Devonian to Mississippian phyllite and schist of the Hayes Glacier belt, project into the study area from the west (Dashevsky and others, 2003) and southeast (Richter, 1973). Both the Jarvis and the Hayes Glacier belts are intruded by numerous Triassic gabbro or diorite sills (Nokleberg and others, 2015; Dashevsky and others, 2003; Foster, 1970; Richter, 1973).

The metamorphic rocks described above are intruded by at least two groups of post-metamorphic felsic plutonic rocks. In the far north of the map area, a very-coarse-grained biotite granite intrudes the Macomb belt 9 miles (14.5 km) southwest of Tok. This intrusion may correlate to mid-Cretaceous (95.7-106.2 Ma) felsic plutonic rocks dated by Solie and others (2014). In the vicinity of VABM Hona and in the Clearwater Creek drainage, dikes, sills, and stocks of fine-grained, porphyritic granodiorite intrude the Jarvis and Macomb belt metamorphic rocks. These intrusions are associated with alteration and mineralization in the Hona area and may be correlated with Late Cretaceous (70 Ma; Illig and Newberry, 2015) plutons 12 miles (19 km) to the east at the Peak Au-Cu skarn (ARDF no.: TC040).

Mafic volcanic rocks of Tertiary or possibly Late Cretaceous age unconformably overlie the metamorphic and plutonic rocks in the area, but these deposits are only locally preserved (Foster, 1970). The area is cut by a series of northeasterly-striking, high-angle faults that are interpreted to be related to dextral strike-slip motion of the Denali and Tintina faults, and therefore active during Tertiary time.

\footnotetext{
${ }^{1}$ Alaska Division of Geological \& Geophysical Surveys, 3554 College Rd, Fairbanks, AK 99709-3707; evan.twelker@alaska.gov

${ }^{2}$ Alaska Division of Geological \& Geophysical Surveys, Geologic Materials Center, 3651 Penland Parkway, Anchorage, AK 99508
} 

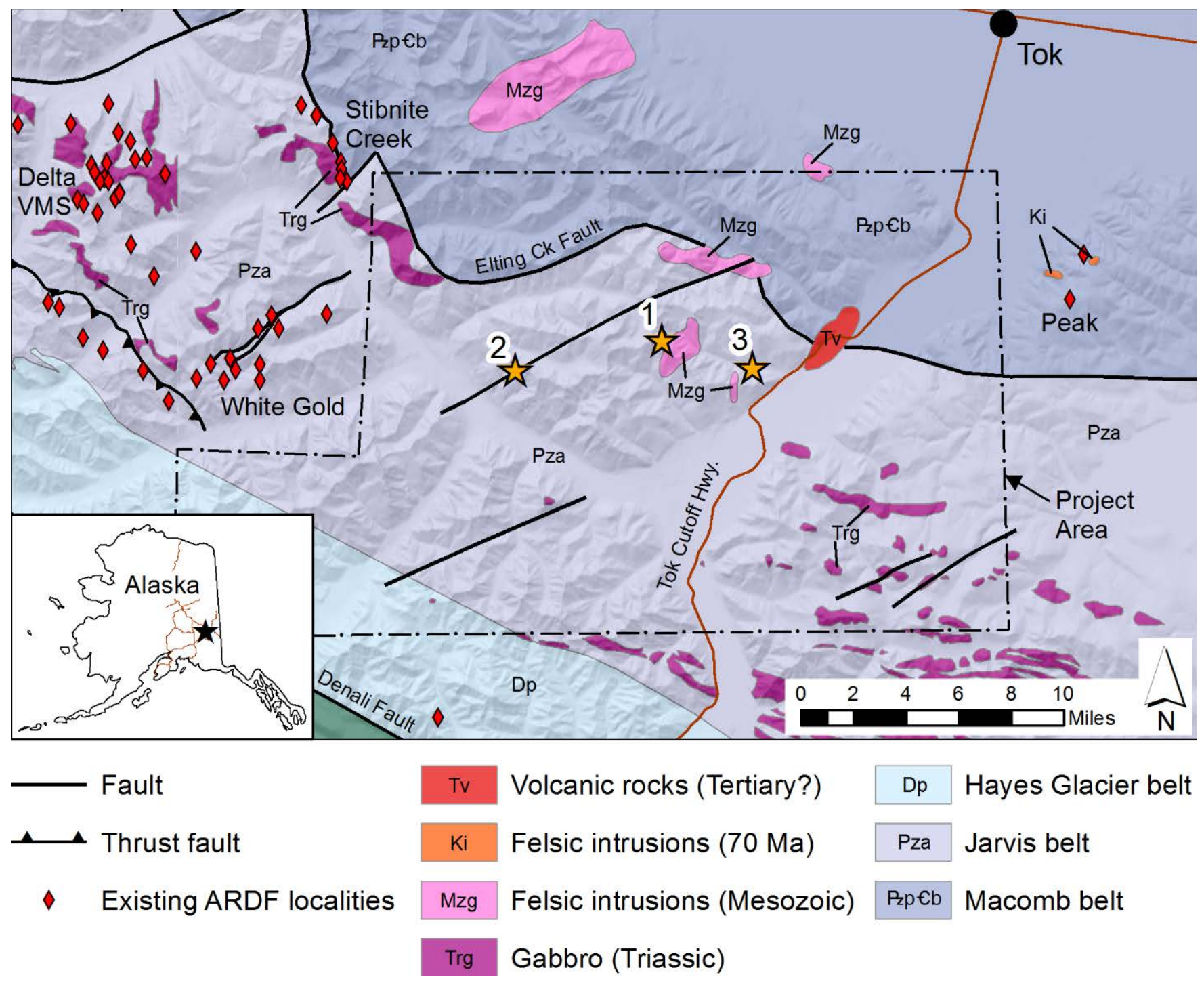

Figure 1. Generalized geologic map modified from Foster (1970), Wilson and others (2015), and Illig and Newberry (2015), illustrating the location and geologic context of the mineral occurrences described in this report. Numbered stars show the locations of (1) Hona; (2) Unnamed, near Tok River and Natohona Creek; and (3) Unnamed, on tributary of the Big Tok River.

\section{Hona (also known as Noah)}

ARDF no.: TC018

\section{Location and accuracy}

Noah prospect is in the general area of the northern half of Section 19, T $16 \mathrm{~N}, \mathrm{R} 11 \mathrm{E}$, of the Copper River Meridian $^{3}$. It is location 21 of Singer and others (1976), 4 miles $(6.4 \mathrm{~km})$ northwest of the Glenn Highway and the Tok River, and about 7 miles $\left(11.3 \mathrm{~km}\right.$ ) west of Clearwater Camp. This locality (latitude $63.15659^{\circ} \mathrm{N}$, longitude $143.40851^{\circ} \mathrm{W}$ ) hosts a mineralized outcrop 0.5 miles west of the drill sites. The location is determined by handheld GPS (estimated $10 \mathrm{~m}$ accuracy), WGS84 datum.

\footnotetext{
${ }^{3}$ Errata, September 8, 2016: Location modified to correct Township/Range/Section/Meridian values.
} 


\section{Major commodities}

$\mathrm{Au}, \mathrm{Cu}, \mathrm{Mo}$

\section{Ore minerals}

Gold, pyrrhotite, arsenopyrite, chalcopyrite, molybdenite, galena

\section{Geologic description}

A roughly 1.5-mi-wide (2.4-km-wide) complex of variably altered porphyritic granodiorite dikes and sills intrudes quartz schist in the area of VABM Hona. Gossanous-weathering portions of the intrusion are moderately sericitized and carry up to several percent disseminated pyrrhotite and pyrite replacing mafic minerals. A grab sample from one such $2.5 \mathrm{~m}$ band ran $0.129 \mathrm{ppm}$ Au and 1,430 ppm As (sample 15LF016 in Wypych and others, 2015). An arsenopyrite-rich pod in quartz schist (fig. 2a) sampled an unknown distance from the intrusive contact ran 14.5 ppm Au, 19 percent As, 305 ppm Bi, 11.1 ppm Te, 526 ppm Cu, and 203 ppm Co (sample 15 ET026 in Wypych and others, 2015).

Other features observed in the prospect area include druzy quartz veins with galena and pyrite, gossanous shear zones with pyrite, and gossanous dacite porphyry with abundant quartz veining and local chalcopyrite. Malachite occurs locally in surface samples (John Hoppe, oral commun., 2016).

Three core holes drilled at the prospect intercepted quartz schist and porphyritic intrusive rocks, and welldeveloped breccias contain rounded clasts of schist and altered intrusive rocks (figs. 2b, c). Thin quartz-carbonate veinlets have feldspathic alteration selvages and contain minor chalcopyrite and molybdenite (fig. 2d).

Previous records (Cameron, 1999; Singer and others, 1976) describe this prospect, which they referred to as the Noah prospect, as a porphyry copper occurrence. While the associated intrusion appears to be shallowly emplaced and has porphyritic to porphyry textures, our geochemical sampling shows little $\mathrm{Cu}$ and indicates levels of $\mathrm{As}, \mathrm{Bi}, \mathrm{Te}$, and $\mathrm{Co}$ that are significantly more enriched than typically would be found in a normal porphyry copper deposit (Halley and others, 2015).

\section{Deposit model}

Intrusion-related gold deposit or porphyry Cu-Au-(Mo) (Cox and Singer, 1986, model 20c)

\section{Age of mineralization}

Cretaceous (post-metamorphic); may be Late Cretaceous based on trace metal similarities to the Peak skarn deposit.

\section{Exploration}

Kennecott Exploration conducted surface exploration and drilling in 1997 and 1998, culminating in three holes drilled in 1998: Hona-1, 854 feet (260 m); Hona-2, 1,297 feet (395 m); and Hona-3, 751 feet (229 m). The Geologic Materials Center in Anchorage holds representative samples ('skeletons') of this core (figs. 2b, c, d). Hona-1 and -2 were collared at $63.16083^{\circ} \mathrm{N},-143.39495^{\circ} \mathrm{W}$; Hona-3 was collared at $63.15819^{\circ} \mathrm{N},-143.40002^{\circ} \mathrm{W}$. The survey method and datum are not known. 

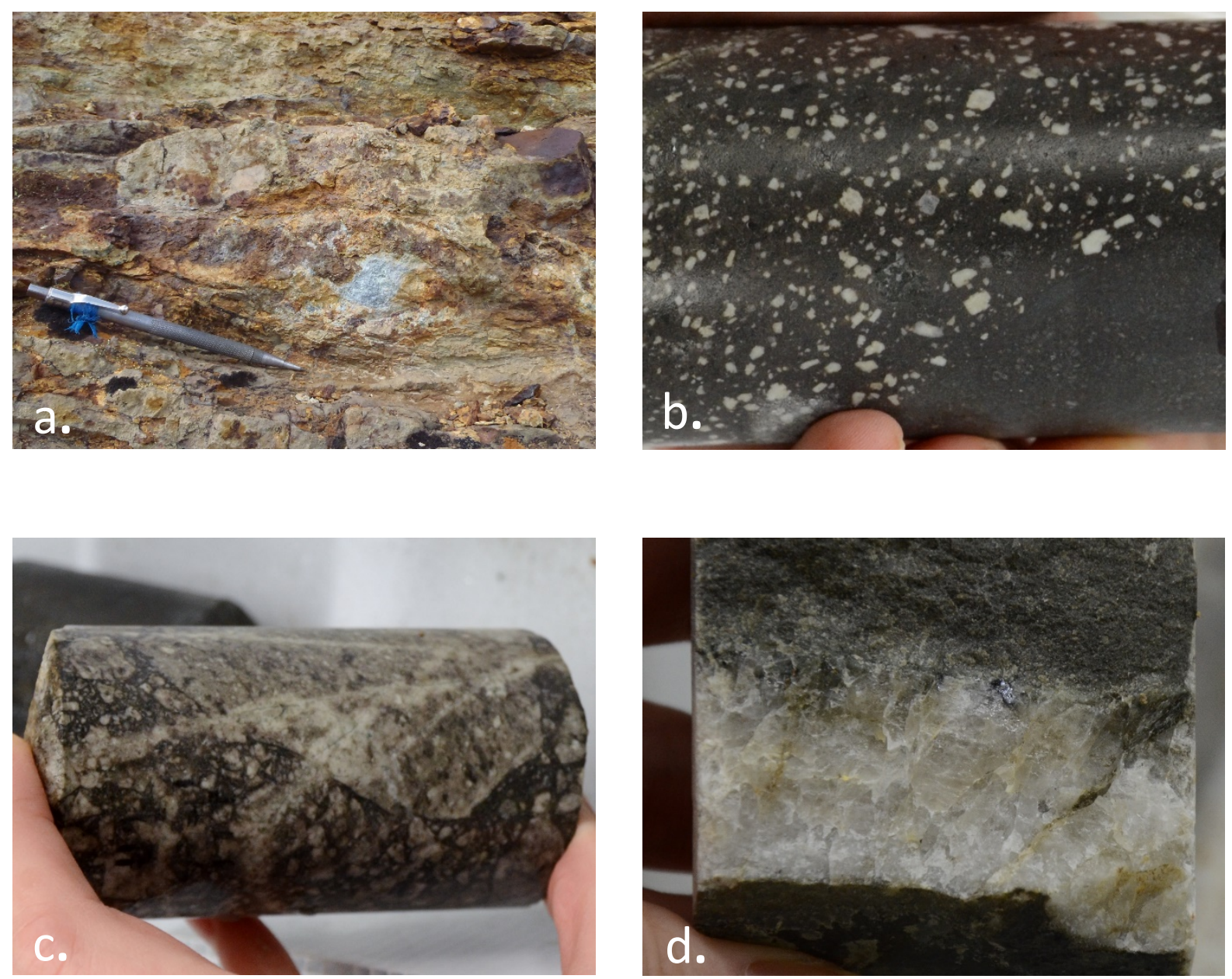

Figure 2. (a) Quartz-sulfide pods in quartz schist at the Hona prospect (sample 15ET026; Wypych and others, 2015); (b) porphyritic intrusive rock (drill hole Hona-2); (c) brecciated intrusive rock with crosscutting veinlets (Hona-2); and (d) molybdenite in quartz veining (Hona-2). Core diameter is 2 inches $(5 \mathrm{~cm})$.

\section{Unnamed (Tok River and Natohona Creek)}

ARDF no.: Not previously documented

\section{Location and accuracy}

This occurrence is on the ridgeline 3 miles $(4.8 \mathrm{~km})$ east of the confluence of the Tok River with Natohona Creek in the southeastern quarter of Section 19, T 16 N, R 10 E, of the Copper River Meridian. Its location of latitude $63.146093^{\circ} \mathrm{N}$, longitude $143.585086^{\circ} \mathrm{W}$ is determined by handheld GPS (estimated $10 \mathrm{~m}$ accuracy), WGS 84 datum.

\section{Major commodity}

$\mathrm{Au}$

\section{Ore and gangue minerals}

Gold, arsenopyrite; quartz and calcite gangue. 


\section{Geologic description}

A northeasterly-trending zone of gossanous-weathering altered and sheared igneous rocks crosses the ridgeline in this location (fig. 3). This zone is roughly $33 \mathrm{ft}(10 \mathrm{~m})$ wide and may represent a dike or strongly altered gabbro. A sample of brecciated and silicified rock in this zone contains about 1 percent very-fine-grained gray sulfide and assayed 1.3 ppm Au, 2.19 percent As, and 352 ppm Sb (sample 15KS007 in Wypych and others, 2015).

Mineralization may be genetically related to a northeasterly-trending, high-angle fault mapped by Foster (1970) in the immediate vicinity. It may also be related to mineralized intrusions at the nearby Hona prospect.

Deposit model

Gold-mineralized polymetallic quartz veins (Cox and Singer, 1986, model 22c).

Age of mineralization

Possibly Late Cretaceous, based on trace-metal similarities to the nearby Hona prospect and the Peak skarn deposit.

\section{Exploration}

This occurrence was sampled during geologic reconnaissance by DGGS (this study).

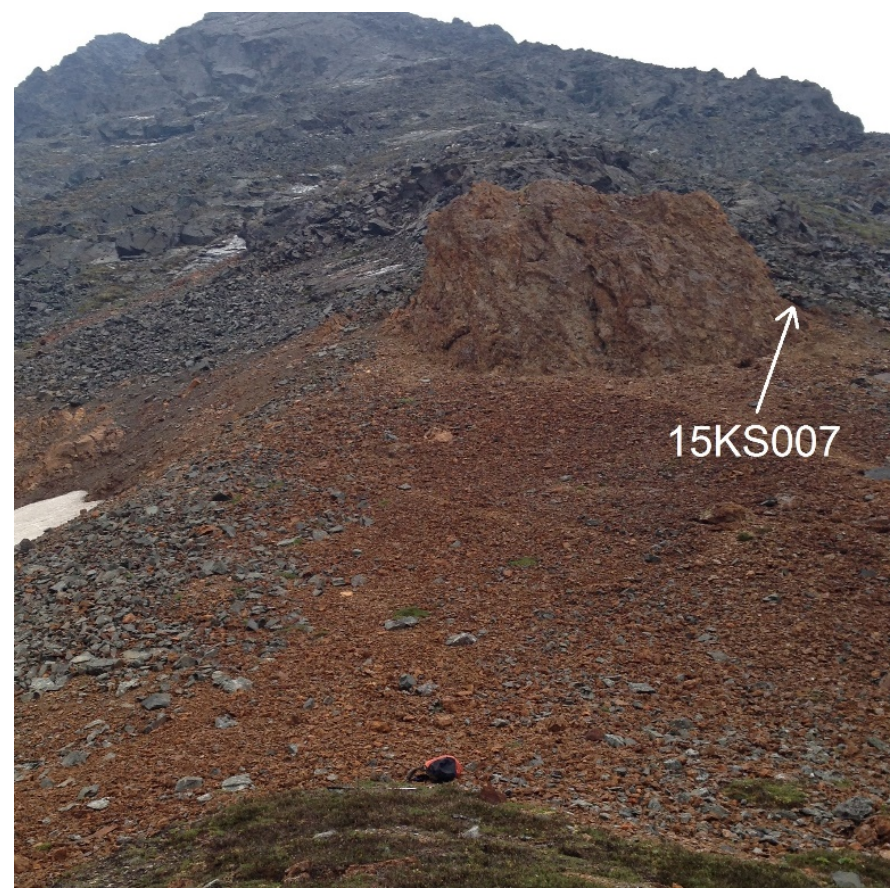

Figure 3. Overview of the mineral occurrence, looking southeast across the zone of gossanous altered and tectonized igneous rock. The darker rocks in the background include gabbro and quartz schist of the Jarvis belt. The arrow indicates the location of mineralized sample 15KSO07. The backpack in the foreground gives a rough indication of the scale. 


\section{Unnamed (Tributary of the Big Tok River)}

ARDF no.: Not previously documented

Location and accuracy

The placer mine is located on the creek draining east from VABM Hona, approximately 1.3 miles ( $2.1 \mathrm{~km})$ upstream from the Tok Cutoff, in the northeast quarter of Section 27, T $16 \mathrm{~N}, \mathrm{R} 11 \mathrm{E}$, of the Copper River Meridian. Its location, latitude $63.143928^{\circ} \mathrm{N}$, longitude $143.300157^{\circ} \mathrm{W}$, is determined by handheld GPS (estimated $10 \mathrm{~m}$ accuracy), WGS84 datum.

Major commodity

$\mathrm{Au}$

Ore minerals

Gold

Geologic description

A DGGS geologist panned seven ragged, $0.1 \mathrm{~mm}$ gold grains and 15 smaller grains in two pans collected from the margin of the placer cut (this study). The placer is downstream from altered and mineralized schist and Cretaceous (?) porphyritic granodiorite at the Hona prospect (ARDF no.: TC018).

Deposit model

Placer Au (Cox and Singer, 1986, model 39a).

Age of mineralization

Quaternary

Workings

Mechanized placer mining took place in 2011 (and possibly earlier) on a small portion of the creek.

Indication of production

Yes; small

\section{ACKNOWLEDGMENTS}

We thank John Hoppe, Kurt Johnson of the Alaska Geologic Materials Center, Jeff Benowitz of the University of Alaska, and DGGS field crew members Alicja Wypych, Lauren Lande, and David Reioux.

This work was funded by the Alaska State Legislature as part of the Airborne Geophysical/Geological Mineral Inventory (AGGMI) program. 


\section{REFERENCES CITED}

Cameron, C.E., 1999, Alaska resource data file, Tanacross Quadrangle: U.S. Geological Survey Open-File Report 99-358, $69 \mathrm{p}$.

Cox, D.P., and Singer, D.A., 1986, Mineral deposit models: U.S. Geological Survey Bulletin 1693, 398 p.

Dashevsky, S.S., Schaefer, C.F., and Hunter, E.N., 2003, Bedrock geologic map of the Delta mineral belt, Tok mining district, Alaska: Alaska Division of Geological \& Geophysical Surveys Professional Report 122, 122 p., 2 sheets, scale 1:63,360. doi:10.14509/2923

Foster, H.L., 1970, Reconnaissance geologic map of the Tanacross Quadrangle, Alaska: U.S. Geological Survey Miscellaneous Geologic Investigations Map 593, 1 sheet, scale 1:250,000.

Halley, S., Dilles, J.H., and Tosdal, R.M., 2015, Footprints-Hydrothermal alteration and geochemical dispersion around porphyry copper deposits: Society of Economic Geologists (SEG) Newsletter, v. 100, p. 1-17.

Illig, P., and Newberry, R.J., 2015, Amphibole Au-Cu skarn and massive sulfide replacement at the Peak Deposit, eastern Interior, Alaska: Proceedings, PACRIM 2015 CONGRESS, p. 1-8.

Nokleberg, W.J., Aleinikoff, J.N., Bond, G.C., Ferrians, O.J., Jr., Herzon, P.L., Lange, I.M., Miyaoka, R.T., Richter, D.H., Schwab, C.E., Silva, S.R., Smith, T.E., and Zehner, R.E., 2015, Geologic maps of the eastern Alaska Range, Alaska (44 quadrangles, 1:63,360 scale), with descriptions and interpretations of map units: Alaska Division of Geological \& Geophysical Surveys Report of Investigation 2015-6, 64 p., 45 sheets, scale 1:63,360. doi:10.14509/29444

Richter, D.H., 1973, Preliminary bedrock geologic map of the Nabesna Quadrangle, Alaska: U.S. Geological Survey Open File Report: Technical Data Unit classification number 563, 2 sheets.

Singer, D.A., Curtin, G.C., and Foster, H.L., 1976, Mineral resources map of the Tanacross Quadrangle, Alaska: U.S. Geological Survey Miscellaneous Field Studies Map 767-E, 1 sheet, scale 1:250,000.

Solie, D.N., O'Sullivan, P.B., Werdon, M.B., Freeman, L.K., Newberry, R.J., Szumigala, D.J., and Hubbard, T.D., 2014, Zircon U-Pb age data, Alaska Highway Corridor, Tanacross and Nabesna quadrangles, Alaska: Alaska Division of Geological \& Geophysical Surveys Raw Data File 2014-16, 29 p. doi:10.14509/27322

Wilson, F.H., Hults, C.P., Mull, C.G, and Karl, S.M, comps., 2015, Geologic map of Alaska: U.S. Geological Survey Scientific Investigations Map 3340, pamphlet 196 p., 2 sheets, scale 1:1,584,000.

http://dx.doi.org/10.3133/sim3340

Wypych, Alicja, Sicard, K.R., Twelker, Evan, Freeman, L.K., Lande, Lauren, and Reioux, D.A., 2015, Major-oxide and trace-element geochemical data from rocks collected in 2015 in the Tok area, Tanacross A-5, A-6, and parts of adjacent quadrangles, Alaska: Alaska Division of Geological \& Geophysical Surveys Raw Data File 2015-15, 3 p. doi: $\underline{10.14509 / 29517}$ 